By another friendly critic a well-grounded objection has been raised to the proposed term 'Cambrian Ice-sheet,' on account of the risk of confusion with the common stratigraphical use of 'Cambrian.' It would, perhaps, be safer to fall back upon the phrase 'Welsh Icesheet' (with subdivision into 'North Welsh' and 'South Welsh' if found desirable).

As previously stated, my more immediate object is especially to urge the adoption of names for the (hypothetical ?) ice-sheets of our sea-basins, for which I have recently felt the pressing necessity. On the terms proposed for the land-areas I do not at present lay much stress, though it would be convenient if these could be fixed at the same time.

G. W. Lamplugh.

Tonbridge.

April 6, 1901.

\title{
THE SODIUM OF THE SEA.
}

SIr,-I am extremely obliged to Mr. Fisher for his kindly notice of my communication concerning the "Sodium of the Sea," but feel at a loss how to reply, owing to uncertainty as to whether Mr. Fisher has considered and rejected De la Beche's articles on Granite and Elvan, Divisional Planes, and Mineral Veins and Faults; or, has possibly overlooked such an ancient authority.

In addition to all that De la Beche and Dr. Sorby have written, and since the last edition of the "Physics of the Earth's Crust," we have the additional fact that all the types of fluid inclusions found in granites may be matched in different quartz-veins, so that all the arguments based on the fluid inclusions in igneous magmas must be prepared to meet the cases of the veins. My object in writing was not so much to defend the sea-water hypothesis, as to remind geologists that it existed. Throughout my own early training I was never allowed to forget that the weakest link in a chain is the measure of its strength, and I knew full well that the slightest slip in fact or argument involved public castigation in the Transactions of the Devonshire Association. If any of the younger geologists in Devonshire erred in discipline our captain, William Pengelly, rarely failed to pipe all hands on deck to witness punishment. Mr. Fisher, I expect, will agree with me that in the present day it is considered of far more consequence that a theory should present a solid appearance than that each link should be tested, and if defective, rejected, not only by the purchaser but by the chainmaker himself.

Foxworthy, Moretonhampstead.

A. R. Hunt. May 7, 1901.

\section{INTERNATIONAL GEOLOGICAL CONGRESS.}

Srr,-I regret that I omitted to express my thanks in my paper, "Geological Notes on Central France," published in the Geological MaGazine (February, 1901, p. 59), to the Directors, MM. Boule, Fabre, and Martel, for their kindness and cousideration during the 
Congress excursion to that region. I did not intend the notes as a narrative of the excursion, only as a small help to friends interested in geology who may not possess that most admirable guide, the "Livret Guide," provided by the Committee for members of the International Geological Congress, over which so much labour must have been expended.

I desire now through the medium of the Geological Magazine to tender my sincere thanks to the Directors, to whom we were all greatly indebted for their kind attention and able discourses.

\section{Hazelwood, Wimbledon Hill.}

M. S. Johnston. April 24, 1901.

\section{THE FISH FAUNA OF THE MILLSTONE GRITS.}

Sir,-May I point out to Dr. Wellburn that the value of his work on Palæozoology will be enhanced if he will take a little more trouble in his method. I read Psephodus, sp. nov., Acanthodes, sp. nov., Euctenodopsis, sp. nov.; but in all these cases I have to dig the specific names out of the text. They should follow the generic name; if they do not they are likely to be overlooked. Those forms which are described, and to which specific names are given by the author, should also have been properly entered up in the table. The specialist will, no doubt, read such papers right through, but that will certainly not be the case of the

OverwheLMED RECORDER.

\section{OBITU ARY. \\ EDWARD CRANE, F.G.S.}

BorN NoveMber 22, 1822.

Dred Apric 25, 1901.

Edward Crane, youngest son of Wright Edward Crane, Esq., landowner, of Thorney, Cambridgeshire, and Mary, his wife, was born November 22nd, 1822. He was educated at Wisbech Grammar School, spent two years fishing and shooting in Ireland, and before he was of age had settled down to the pursuit of agriculture as a tenant farmer on the Duke of Bedford's model Thorney estate. In 1851 he married Jane Turnell, eldest child of a neighbouring farmer, and remained in Thorney until 1866, when he retired and went to live at first in the vicinity of the Crystal Palace. Soon afterwards, accompanied by his wife and daughter, he visited the continent of Europe, and, returning to England in November, 1867, settled in Brighton; having purchased a house in Wellington Road, he resided there until his sudden death on April 25th, 1901.

When the town Museum was removed from the Pavilion rooms to the present building in Church Street, Edward Crane assisted in arranging the geological gallery. He became a member of the Museum Sub-Committee in 1873 during the Chairmanship of his 